\title{
ALMANYA SOSYAL BILGILER ÖĞRETMENI YETIŞTIRME PROGRAMI
}

\section{Social Studies Teacher Training Program in Germany}

Şükrü Bilici

Orcid: 0000-0002-2124-4341/Muş Alparslan Üniversitesi, Eğitim Fakültesi.

Hüseyin Bedirhanoğlu

Orcid: 0000-0002-8980-6267/Muş Alparslan Üniversitesi, Fen Edebiyat Fakültesi.

\section{MAKALE BILGISI}

Makale Geçmişi:

Başvuru tarihi: 26 Mar 2020

Düzeltme tarihi: 16 April 2020

Kabul tarihi: 25 Mayıs 2020

Anahtar Kelimeler:

Almanyada eğitim, öğretmen yetiştirme, sosyal bilgiler, staatexamen, Lehramt.
ÖZ

Dünyanın farklı ülkelerinde "Sosyal Bilgiler" dersleri işlenmektedir. Federal Almanya Cumhuriyetinde tarih, coğrafya, değerler ve normlar, toplum bilinci dersleri ve sosyal bilgiler dersleri ayrı işlenmektedir. Almanyada üniversitelerde Sozialkunde (Sosyal bilgiler) dersleri farklı eyaletlerde okutulmaktadır. Bu çerçevede Almanya'da Sosyal bilgiler öğretmeni yetiştirme sisteminin incelenmesi farklı bir bakış açııı kazandırmayı amaçlamaktadır.

Bu araştırmada nitel araştırma yöntemlerinden doküman incelemesi tekniği kullanılarak Alman eğitim sistemi içerisinde sosyal bilgiler öğretmeni yetiştirme programı incelenerek konu ile ilgili dökümanlar analiz edilmeye çalışılmıştır. Almanya sosyal bilgiler öğretmenliği yetiştirme programı incelendiğinde önemli farklılıkların olduğu gözlenmiştir. Bu farklılıkların başında ders içerikleri yer almaktadır. Sosyal Bilgiler (Sozialkunde) ders içeriğinde sosyoloji, siyaset bilimi ve çağdaş tarih konularına yer verildiği görülmektedir. Almanyada Lisans (Bachelor) eğitimini tamamlayarak Birinci devlet sınavını (Staatexamen) kazanan öğretmenler atandıktan sonra iki yıl stajerlik eğitimi almaktadır. Aday öğretmenler iki uzmanın kontrolünde öğretmenlik mesleğini tüm yönleriyle yerine getirmeye çalışır. Bu süre sonunda yapılan ikinci devlet sınavının başarılmasıyla asil öğretmenlik yapmaya hak kazanırlar.

\section{ABSTRACT}

"Social Studies" courses are taught in different countries of the world. Federal Republic of Germany history, geography, values and norms, social awareness courses and social studies courses are taught separately. Sozialkunde (Social studies) courses in universities in Germany are taught in different states. In this context, the study of the social studies teacher training system in Germany aims to gain a different perspective.

In this study, it was tried to analyze the documents related to the subject by examining the social studies teacher training program in the German education system by using document analysis technique, which is one of the qualitative research methods. When the German social studies teacher education program is examined, it is observed that there are important differences. Course content is at the top of these differences. It is seen that the subjects of sociology, political science and contemporary history are included in the content of Social Studies (Sozialkunde). After completing the Bachelor education in Germany, the teachers who have passed the First State Exam (Staatexamen) receive two years of internship training. Prospective teachers try to fulfill the teaching profession in all aspects under the control of two experts. With the success of the second state exam held at the end of this period, they are entitled to become principal teachers.

Sorumlu yazar/Corresponding author.

e-posta: s.bilici@alparslan.edu.tr. 


\section{Giriş}

Cumhuriyetin ilanından sonra işlenmeye başlanan sosyal bilgiler dersleri değişik isimler altında işlenegelmiştir. Çeşitli isimler altında işlenen sosyal bilgiler dersi son olarak Milli Tarih ve Milli Coğrafya derslerinin birleştirilmesiyle sosyal bilgiler adını almıştır. Yapılandırmacı eğitim yaklaşımına uygun öğretim programında sosyal bilimlerin hemen tüm alanlarını kapsayacak içeriklere rastlamak mümkündür (Tonga, 2012). Tarih, coğrafya ve vatandaşlık konularına ise ağırlıkı olarak yer verilmektedir. Sosyal bilgiler, sosyal bilimler alanındaki bilgi ve bulguların belli bir müfredat çerçevesinde işlenmesinden oluşan bir derstir. Ortaokul düzeyinde verilen bu derslerde öğrencilerin sosyal bilimler alanındaki bilgileri kavramaları amaçlanmaktadır. Bu bilgilere ek olarak iyi insan ve iyi vatandaş yetiştirme hedefi de ön plana çıkmaktadır.

Dünya ülkelerinin eğitim sistemleri incelendiğinde "Sosyal Bilgiler" adıyla dersler işlendiği görülmektedir. Amerikada sosyal bilgiler dersinde tarih, coğrafya ve vatandaşlık eğitimi konularına ağırlık verilmektedir. Yüzyılı aşkın bir tarihi olan sosyal bilgiler dersi farklı kültürlere ve etnik kökenlere karşı hoşgörülü bir anlayışın öğrenciler tarafından anlaşılabilmesini hedeflemektedir. Ortaokul düzeyinde okutulan dersler ile ilgili çeşitli komisyonlar oluşturulmuş ve çok sayıda yayın yapılmıştır. Bazı ülkelerde farklı derslerde sosyal bilgiler ve vatandaşlık konuları işlenmektedir. Federal Almanya Cumhuriyetinde tarih, coğrafya, değerler ve normlar ile toplum bilinci, sosyal bilgiler ve vatandaşlık dersleri işlenmektedir. Üniversitelerde Sozialkunde (Sosyal bilgiler) bölümleri yer alırken bazı eyaletlerde sosyal bilgiler dersleri okutulmaktadır. Okullarda ders olarak okutulan sosyal bilgiler derslerinin öğretiminde en çok etkin olacak alan öğretmenlerinin yetiştirilmesinin önemi büyüktür. Bu çerçevede diğer ülkelerin öğretmen yetiştirme sistemlerinin incelenmesi Türkiye'de uygulanan öğretmen yetiştirme sistemine yeni bir bakış açısı kazandırması ve daha iyi anlaşılmasını sağlaması beklenebilir.

Almanyada sosyal bilgiler öğretmenleri nasıl yetiştirilmektedir? Almanyada yükseköğretim kurumlarında öğretmenler hangi aşamalardan geçmektedirler ve kaç yıllık bir eğitim görmektedirler? Uygulama dersleri nasıl işlenmektedir ve ne kadar sürmektedir. Almanya'da sosyal bilgiler öğretmeni yetiştirme sisteminde hangi derslere ağırlık verilmektedir? Yukarıda belirtilen sorulara verilen cevaplar ile Almanyada sosyal bilgiler öğretmeni yetiştirme sisteminin ortaya konulması amaçlanmaktadır. Bu araştırmada Nitel araştırma yöntemlerinden doküman incelemesi tekniği kullanılmıştır. Alman eğitim sistemi içerisinde öğretmen yetiştirme programlarının inceleneceği bu çalışmada, konu ile ilgili dökümanlar analiz edilmeye çalışılmıştır. Araştırma kapsamında, araştırmaya konu olan sosyal bilgiler öğretmen yetiştirme sistemi incelenmiştir.

\section{Araştırmanın Amacı}

Türkiye'de Sosyal Bilgiler Öğretmeni yetiştirme programında lisans eğitiminden sonra merkezi sınav ile öğretmen ataması yapılmaktadır. Ataması gerçekleşen öğretmenler bir yıl süre ile stajyer öğretmen statüsünde çalışmaktadır. Bu süre içerisinde bazı eğitimlerden geçmekte ve sürecin bitiminde hazırlanan raporlar doğrultusunda asil öğretmenliğe geçişleri yapılmaktadır. Lisans eğitiminden sonraki süreçte öğretmenlerin daha kapsamlı bir eğitime tabi tutulmaları ve uygulama boyutundaki yeterliklerinin daha da geliştirilmesi açısından Federal Almanya Cumhuriyeti sosyal bilgiler öğretmeni (Sozialkunde) yetiştirme sisteminin incelenmesinin olumlu katkılar sunacağı amaçlanmaktadır.

\section{Araştırmanın Yöntemi}

Araştırmada nitel araştırma yöntemlerinden doküman analizi tekniği kullanılmıştır. Almanya ve Türkiye'de Sosyal Bilgiler Öğretmeni yetiştirme programı kapsamında döküman ve yayınlar incelenmiştir. Almanya'daki üniversitelerde Sosyal Bilgiler Öğretmenliği (Sozialkunde) bölümleri incelenerek üniversite ve bölümler tablo haline getirilmiştir. Almanyada Sosyal Bilgiler Öğretmenlerinin yetiştirme lisans ve lisans sonrası süreci de içerisinde alacak şekilde incelenmiştir. Öğretmenlerin lisans Sorumlu yazar/Corresponding author. e-posta: musagumus@hotmail.com. 
eğitiminde gördükleri dersler ile öğretmen atama süreçleri ortaya konulmuştur. Almanyada öğretmenlerin atandıktan sonraki yetiştirlme süreçleri verilerek bazı sonuçlara ulaşılmıştır.

\section{Alman Eğitim Sistemi}

Alman eğitim sisteminin çok çeşitliliği uzun bir süreçte oluşmuş günümüzdede varlığını sürdürmektedir (Kricke, 2014). Eyaletlere göre de farklılık gösteren eğitim sisteminde eyaletlerin kendilerine özgü bir eğitim sistemşi oluşturmalarına imkân verilmektedir. Tüm eyaletlerde zorunlu eğitim süresi 12 yıl olan Almanyada ilk ve ortaöğretim 6-18 yaş arasındaki çocuk ve gençleri kapsar (Demirel, 2000; Kantos, 2009). Bu sürenin 10 yılı tam zamanlı öğretim yapılan genel eğitim okullarında geçirilmesi zorunludur (Sağlam, 1999). Alman eğitim sistemi içerisinde ilkokulun (Grundstufe) ayrı bir yeri vardır. İlkokul döneminde temel eğitim ile ilgili dersler okutulmaktadır. Öğrencilere 1 . sınıftan başlamak üzere 4. sınıf da dâhil olmak kaydıyla dersler verilir. Altı yaşını doldurmuş olan öğrenciler zorunlu eğitime başlar. Eğitm 18 yaşına kadar sürer. 10 yıllık tam zamanlı eğitimden sonra yarı zamanlı olarak iki yıl daha eğitim devam eder (Führ, 1997).

Alman Eğitim Sisteminde okullar, Primarschule (Okul Öncesi), Grundschule (ilkokul) Sekundarstufe I (Ortaokul I Kademe), Sekundarstufe II. (Ortaokul II Kademe) Sonderschule (Özel eğitim okulları) ve yükseköğretim okulları olarak belirlenmiştir. Ortaokullar dört farklı okul türünden oluşmaktadır. Mittelschule (ortaokul) döneminideki öğrencilerin eğitim gördüğü bu okullar Hauptschule, Realschule, Gesamtschule ve Gymnasium olarak adlandırılmaktadır.

\section{Almanyada Sosyal Bilgiler Öğretmeni Yetiştirme Programı}

Almanyada üniversiteler ve enstitüler bünyesinde öğretmenlik eğitimi verilmektedir. Üniversiteler, eğitim enstitüleri, müzik ve sanat eğitimi okullarından yetişen öğretmenler bu mesleği icra etmeye hak kazanmaktadırlar. Farklı üniversitelerdeki öğretmen yetiştirme programlarına kayıt yaptırabilmek için Almanya'da öğrencilerin "Abitur" sınavını başarıyla geçmeleri gerekmektedir (Keçici, 2011). Bir diğer adı da olgunluk sınavı olan bu sınav neticesinde üniversiteye giriş yapan adaylar eğitim almaya başlaamaktadır. En az üç yıl süren üniversite eğitiminin ardından üniversiteden mezun olan öğretmen adayları birinci devlet sınavına (Staatexamen) girmeye hak kazanırlar (Sözen ve Çabuk, 2013). Bu sınav yazılı ve sözlü olmak üzere iki aşamada gerçekleştirilmektedir. Bu sınavdan başarılı olan adaylar stajyer öğretmenlik (18-24 ay) yapmaya başlarlar. Stajyer öğretmenlik süresini doldurduktan sonra sınava girme hakkını kazanmaları halinde ikinci devlet sınavına (Staatexamen) girmek zorundadırlar. Yine yazılı ve sözlü olmak üzere iki aşamadan oluşan ikinci devlet sınavının başarılı bir şekilde kazanmaları halinde asil öğretmen olarak atanmaktadırlar. Bu aşamalardan geçerek öğretmen olan kişiler devlet memuru statüsünü kazanırlar.

Almanyanın birçok üniversitesinde Sosyal bilgiler (Sozialkunde) bölümü bulunmaktadır. Sosyal bilgiler bölümü genel olarak Lehramt (eğitim) ve Sozialwissenschaften (Sosyal bilimler) fakülteleri bünyelerinde yer almaktadır. Grundschule (ilkokul), Hauptschule (Ortaokul), Realschule (Ortaokul ve lise), Gesamtschule (Ortaokul ve lise) ve Gymnasium (Ortaokul ve Lise) okullarında sozialkunde (Sosyal Bilgiler) derslerini vermek üzere öğretmenler yetiştirilmektedir. Öğretmen adaylarının üniversitedeki teorik derslerin yanında uygulama derslerini de başarıyla tamamlamaları gerekir. Temel eğitim ve uygulama eğitimini başarıyla tamamlayıp sınavları kazanan öğretmen adaylar Sosyal bilgiler derslerini vermektedir.

\section{Üniversitelerde Sosyal Bilgiler Öğretmenliği}

Almanyada sosyal bilgiler öğretmeni yetiştiren üniversiteler.

\begin{tabular}{|l|l|}
\hline ÜNIVERSiTE & BÖLÜM. \\
\hline Augsburg & Sozialkunde (Lehramt an Mittelschulen) ortaokul öğretmenliği \\
\hline Augsburg & Sozialkunde (Lehramt an Gymnasien) ortaokul-lise öğretmenliği \\
\hline Augsburg & Sozialkunde (Lehramt an Realschulen) ortaokul öğretmenliği \\
\hline
\end{tabular}




\begin{tabular}{|c|c|}
\hline Bamberg & $\underline{\text { Sozialkunde (Lehramt an Mittelschulen) ortaokul öğretmenliği }}$ \\
\hline Bamberg & Sozialkunde (Lehramt an Gymnasien) ortaokul-lise öğretmenliği \\
\hline Eichstätt & $\underline{\text { Sozialkunde (Lehramt an Hauptschulen) ortaokul öğretmenliği }}$ \\
\hline Eichstätt & $\underline{\text { Sozialkunde (Lehramt an Gymnasien) ortaokul-lise öğretmenliği }}$ \\
\hline Erlangen & Sozialkunde (Lehramt an Gymnasien) ortaokul-lise öğretmenliği \\
\hline Erlangen & $\underline{\text { Sozialkunde (Lehramt an Realschulen) ortaokul öğretmenliği }}$ \\
\hline Halle & $\underline{\text { Sozialkunde (Lehramt an Gymnasien) ortaokul-lise öğretmenliği }}$ \\
\hline Halle & $\underline{\text { Sozialkunde (Lehramt an Sekundarschulen) ortaokul öğretmenliği }}$ \\
\hline Jena & Sozialkunde (Lehramt an Gymnasien) ortaokul-lise öğretmenliği \\
\hline Kaiserslautern & $\underline{\text { Sozialkunde (Lehramt an Realschulen) ortaokul öğretmenliği }}$ \\
\hline$\underline{\text { Kaiserslautern }}$ & $\underline{\text { Sozialkunde (Lehramt an Gymnasien) ortaokul-lise öğretmenliği }}$ \\
\hline$\underline{\text { Kaiserslautern }}$ & Sozialkunde (Master of Education) yüksek lisans (Gymnasien) \\
\hline Kaiserslautern & Sozialkunde (Master of Education) yüksek lisans (Realschule) \\
\hline Landau & Sozialkunde (Lehramt an Realschulen) ortaokul öğretmenliği \\
\hline Landau & Sozialkunde (Lehramt an Gymnasien) ortaokul öğretmenliği \\
\hline Landau & Sozialkunde (Master of Education) yüksek lisans (Gymnasien) \\
\hline Landau & Sozialkunde (Master of Education) yüksek lisans (Realschule) \\
\hline Mainz & Sozialkunde (Lehramt an Gymnasien) ortaokul öğretmenliği \\
\hline München & Sozialkunde (Lehramt an Mittelschulen) ortaokul öğretmenliği \\
\hline München & $\underline{\text { Sozialkunde (Lehramt an Realschulen) ortaokul öğretmenliği }}$ \\
\hline München & Sozialkunde (Lehramt an Gymnasien) ortaokul öğretmenliği \\
\hline Nürnberg & Sozialkunde (Lehramt an Mittelschulen) ortaokul öğretmenliği \\
\hline Passau & Sozialkunde (Lehramt an Mittelschulen) ortaokul öğretmenliği \\
\hline Passau & Sozialkunde (Lehramt an Realschulen) ortaokul öğretmenliği \\
\hline Passau & $\underline{\text { Sozialkunde (Lehramt an Gymnasien) ortaokul öğretmenliği }}$ \\
\hline Regensburg & $\underline{\text { Sozialkunde (Lehramt an Mittelschulen) ortaokul öğretmenliği }}$ \\
\hline Rostock & Sozialkunde (Lehramt an Gymnasien) ortaokul öğretmenliği \\
\hline Trier & Sozialkunde (Lehramt an Gymnasien) ortaokul öğretmenliği \\
\hline Trier & Sozialkunde (Master of Education) yüksek lisans (Realschule) \\
\hline Würzburg & $\underline{\text { Sozialkunde (Lehramt an Mittelschulen) ortaokul öğretmenliği }}$ \\
\hline Würzburg & Sozialkunde (Lehramt an Gymnasien) ortaokul öğretmenliği \\
\hline
\end{tabular}

(www.studienwahl.de)

\section{Sosyal Bilgiler "Sozialkunde" Eğtitim Fakültesi Gymnasium / Branş Alanı (Münih Üniversitesi)}

Sosyal bilgiler eğitimi bilim dalı üç değişik alandan meydana gelmektedir. Siyaset bilimi, Sosyoloji ve günümüz tarihi. Siyaset bilimi alanı, politik teori, felsefe (Antik çağdan günümüze) ve siyasi sistemlerden oluşmaktadır. (Özellikle Almanya'nın siyasi sistemi) ve uluslararası ilişkiler öne çıkmaktadır. Sosyoloji bilim alanı, sosyolojinin temelleri (sosyolojiye giriş ve bilimsel çalışmalar), sosyoloji teorileri (giriş seminerleri, alıştırmalar üzerinde derinleşme) nicel metotlar, sosyal yapı analizi, sosyal değişim ve sosyal farklılıkları içermektedir. Günümüz tarihi alanında ise tarihi devirlerden 1945 yıına kadarki olan tarih ön plana çıkmaktadır. 


\section{Eğitimin yapılandırılması / Modüller}

Öğretmenlere verilen eğitim kapsamında öğretmen adaylarının alan bilgisi üzerine çalışmalar yapması, öğretilecek konular arasındaki bağlantıyı iyi görmeleri, başkalarıyla iyi ilişkiler kurabilmeleri ve özellikle gençlerle sağlıklı bir iletişim kurmaları amaçlanmaktadır. Bunun yanında Alman toplumunda geleneksel değerlerin gençlere kazandırılması yasal bir yükümlülük olarak görülmektedir (Kempf, 2002; Harder, 2014). Yüksek eğitim hakkını kazanma aşamasında yani Abitur döneminde edindiği bilgileri korumakla beraber sosyal bilgiler alanındaki gereksinimleri, özel yeteneklerini ortaya koyması beklenir. Siyaset bilimi ve sosyolojik konuları kavraması, yansıtma yeteneğini kazanması, yazma, iyi düzeyde İngilizce öğrenme, bağımsız düşünme ve çalışma gibi bireysel becerilerini geliştirmesi istenir. Ayrıca eğitim yönetimi ve sınav uygulamalarını zorunlu müfredata uydurma kazanımını elde etmesi istenir Münih üniversitesinde Sozialkunde (Sosyal bilgiler) bölümü incelendiğinde Eğitim süresince öğretmen adaylarının 10 adet zorunlu modül almaları gerektiği görülmektedir. Modüller, bir modül sınavı (Mobil Prüfung) veya iki kısmi modül sınavı şeklinde ölçülür. Sosyal Bilgiler eğitimi, siyaset bilimi içerisindeki üç alt dalı kapsar. Siyaset bilimi (4 Modül, 45 ECTSkredi), Soziologie (3 Modül, 36 ECTS-kredi) ve günümüz tarihi (1 Modül, 12 ECTS-kredi). Bilim alanında teorik ve analitik uygulama eğitimi verilir. Uzmanlık alanı yanında, formasyon konuları ile eğitim tamamlanır. Bu eğitim bağımsız modülleri kapsar. Bu modüller 3 dersi kapsar (toplam 12 ECTS-kredi). Eğitim bilimleri konuları siyaset bilimi okulu enstitüsü tarafından verilir (www.unimuenchen.de)

\section{Formasyon ve Uygulama Eğitimi}

Münih Üniversitesinde formasyon eğitimi, pedagoji, okul pedagojisi ve psikoloji gibi alanlardan oluşmaktadır. Bu üç alandan toplam 36 ECTS kredisi alınması gerekir. Eğitim fakültesi bölümlerinden birine kayıt yaptırmıs olan öğrenciler aşağıdaki uygulamaları yapmak zorundadır: Staj, oryantasyon uygulaması, pedagojik, eğitim bilimleri okul uygulaması (okul uygulaması 150 - 160 ders saatinden oluşmaktadır). Bu dersler ard arda iki yarıyılda alınır. Öğretmen eğitimi veren kurumlardaki meslekî uygulamalarda eyaletlere göre bazı farklılıklar olmasına rağmen genelde üç tür uygulamadan söz edilebilir: Oryantasyon Uygulaması, meslek bilgisini derinleştirme uygulaması, alan ve yan alan uygulaması. Alan ve yan alan uygulaması lisans eğitiminden sonra gerçekleşmektedir. (www.unimuenchen.de). Uygulamaların genel amacı çok yönlü yeterlik kazanma, eleştirel yaklaşım yoluyla muhakeme gücünü arttırma, okul, program, yöntem ve eğitim sürecini sorgulayabilecek ve geliştirebilecek düzeyde yeterlik kazandırma olarak ifade edilebilir.

\section{Oryantasyon Uygulaması (Orientierungspraktikum)}

Bu uygulamanın temel amacı öğretmen adayının öğretmen ve öğrencilerle edindiği deneyimler ışığında kendisinin bu mesleğe uygunluğu ve yatkınlı̆̆ hakkında daha gerçekçi fikir sahibi olmasını sağlamaktır. Öğretmen adayları 2. veya 3. yarıyılda bir yarıyıl boyunca "uygulama günü" adı altında haftanın bir günü 5 ile 8 kişilik gruplar halinde okullara giderler. Buralarda tecrübeli öğretmenleri izleme, bu gözlemleri rapor haline getirme ve isteğe bağlı olarak da ders anlatma etkinliklerinde bulunurlar. Bu uygulama öğretmen yetiştiren kurumlara bağlı olarak bütünleştirilmiş şekilde dört hafta boyunca her gün olmak üzere de gerçekleştirilebilir. Öğretmen adaylarının bu etkinliklerine yönelik geliştirilen değerlendirme formları, akademik danışman ve öğretmen tarafından doldurulur. Bunların analizi ve raporlaştırııması öğretmen adayı, öğretmen ve akademik danışmanla birlikte yapılır.

\section{Meslek Bilgisini Derinleştirme Uygulaması (Vertiefendes Praktikum)}

Bu uygulama genellikle 4. ve 5. yarıyılda yapılır. Formasyon ağırlıklı olup alana yönelik özel öğretim yöntem bilgilerini kapsar. Temel amacı, öğretmen adayının okul programını ve okulun yakın çevresini, okulun fiziki donanımını (sınıfları, laboratuarları, kütüphaneyi, okul bahçesini), okul yönetimi ve bürokrasisini, derslerin amaç ve içeriklerini, öğretim strateji ve yöntemlerini ve ders içi iletişim sürecini analiz edip değerlendirmesidir. Bu süreçte öğretmen adayının ders planı hazırlayacak ve ders etkinliklerini etkili ve verimli bir biçimde gerçekleştirebilecek düzeye gelmesi hedeflenir. Özel uzmanlar eşliğinde gerçekleştirilen bu uygulamada, öğretmen adayı gözlem yapmanın yanında, ders hazırlayıp sunmak zorundadır. Öğretmen adaylarını değerlendirme amacıyla bu uygulamalar için hazırlanmış 
değerlendirme formları rehber ve uzmanlarca doldurulmaktadır. Bunun dışında dersler 8 ve 9 semester eğitimi döneminde seçmeli olarak siyaset bilimi veya sosyolojiden bir alan seçilebilir. ìki seçenek de öğrenciye sunulur (www.unimuenchen.de).

Sosyal bilgiler öğretmeni yetiştirme programlarında işlenen dersler (Münih Üniversitesi Sosyal bilimler Fakültesi Sosyal Bilgiler Bölümü Gymnasium Öğretmenliği bölümü)

\begin{tabular}{|c|c|c|c|c|}
\hline Ders Dönemi & Zorunlu modül & Dersler & Etkinlik şekli & ECTS \\
\hline 1 (kış dönemi) & P1 Sosyolojiye Giriş & $\begin{array}{l}\text { Sosyolojiye Giriş } \\
\text { Sosyolojiye Giriş } \\
\text { Bilimsel Çalışma } \\
\text { Düşünce Tarihi ve Politik Eğitim } \\
\text { Konsepti }\end{array}$ & $\begin{array}{l}\text { Ders } \\
\text { Uygulama } \\
\text { Uygulama } \\
\text { Seminer }\end{array}$ & $\begin{array}{l}4 \\
2 \\
3 \\
3\end{array}$ \\
\hline 2 (yaz dönemi) & $\begin{array}{l}\text { P2 Sosyolojik Teori } \\
\text { P3 Kantitatif Metotlar }\end{array}$ & $\begin{array}{l}\text { Sosyolojik Teoriler } \\
\text { Teori } 2 \\
\text { Metotlara ve Kantitativ Sosyal } \\
\text { bilimlere Giriş } \\
\text { Metotlara ve Kantitativ Sosyal } \\
\text { bilimlere Giriş }\end{array}$ & $\begin{array}{l}\text { Ders } \\
\text { Uygulama } \\
\text { Ders } \\
\text { Uygulama }\end{array}$ & $\begin{array}{l}3 \\
3 \\
4 \\
2\end{array}$ \\
\hline 3 (kışdönemi) & P4 Politik Sistemler & $\begin{array}{l}\text { Almanyanın Politik Sistemi } \\
\text { Politik Sistem Temel Kursları } \\
\text { Politik Sistemler (Ayrıntılı) }\end{array}$ & $\begin{array}{l}\text { Ders } \\
\text { Temel kurs } \\
\text { Ders }\end{array}$ & $\begin{array}{l}3 \\
6 \\
3 \\
\end{array}$ \\
\hline 4 (yaz dönemi) & P5 Uluslararası İlişkiler & $\begin{array}{l}\text { Uluslararası Iliş̧iler } 1 \\
\text { Uluslarrası Temel Kursu } \\
\text { Karşılaştırmalı Siyaset Bilimi }\end{array}$ & $\begin{array}{l}\text { Ders } \\
\text { Temel kurs } \\
\text { Ders }\end{array}$ & $\begin{array}{l}3 \\
6 \\
3\end{array}$ \\
\hline 5 (kış dönemi) & P6 Çağdaş Tarih & $\begin{array}{l}\text { Birinci Dünya Savaşı } \\
1945 \text { 'ten Sonraki Temel Problemler }\end{array}$ & $\begin{array}{l}\text { Uygulama } \\
\text { Uygulama }\end{array}$ & $\begin{array}{l}6 \\
6\end{array}$ \\
\hline 6 (yaz dönemi) & P7 Avrupa & $\begin{array}{l}\text { Avrupanın Entegrasyonu } \\
\text { Avrupa Entegrasyonu Üzerine } \\
\text { Uygulamalar } \\
\text { Siyaset Teorisi } 2\end{array}$ & $\begin{array}{l}\text { Ders } \\
\text { Uygulama } \\
\text { Ders }\end{array}$ & $\begin{array}{l}3 \\
6 \\
3\end{array}$ \\
\hline 7 (kış dönemi) & $\begin{array}{l}\text { P8/I Sosyal Yapı Analizi } \\
\text { Gymnasiumda Sosyal } \\
\text { Bilgiler Eğitimi }\end{array}$ & $\begin{array}{l}\text { Sosyal Yapı Analizi } \\
\text { Sosyal Yapı Analizi } \\
\text { Planlama, Gymnasiumda Sosyal } \\
\text { Bilgiler Derslerinde Siyaset Eğitimi } \\
\text { Metodu }\end{array}$ & $\begin{array}{l}\text { Ders } \\
\text { Uygulama } \\
\text { Seminer }\end{array}$ & $\begin{array}{l}(4+2) 6 \\
(3+3) 6\end{array}$ \\
\hline 8 (yaz dönemi) & $\begin{array}{l}\text { P9/II Sosyal Yapı Analizi } \\
\text { Gymnasium'da Sosyal } \\
\text { Bilgiler Eğitimi }\end{array}$ & $\begin{array}{l}\text { Sosyal Kurumlar/ Sosyal Değişim/ } \\
\text { Sosyal Farklılıklar } \\
\text { Siyaset Eğitimi Prensipleri }\end{array}$ & $\begin{array}{l}\text { Seminer } \\
\text { Seminer }\end{array}$ & $\begin{array}{l}9 \\
3 \\
\end{array}$ \\
\hline 9 (kış dönemi) & P10 Siyaset Teorisi & $\begin{array}{l}\text { Siyaset Teorisi } 1 \\
\text { Siyaset Teorisi Temel Kursu }\end{array}$ & $\begin{array}{l}\text { Ders } \\
\text { Temel Kurs }\end{array}$ & $\begin{array}{l}3 \\
6 \\
\end{array}$ \\
\hline
\end{tabular}

(www.uni-muenchen.de 29.02.2020)

\section{Üniversite Sonrası Öğretmen Yerleştirme ve Yetiştirme Programı}

Almanya'da öğretmen eğitimi iki aşamadan oluşmaktadır; birinci aşama fakültedeki eğitim aşaması, ikinci aşama ise stajyer öğretmenlik aşamasıdır. Öğretmen adayları fakültede aldıkları eğitimi tamamladıktan sonra, birinci Kamu Personeli Sınavına (I. Staatsexamen) girerler. Bu sisteme göre, uygulama eğitimi öğretmen yetiştiren kurumda ve stajyerlik döneminde olmak üzere iki bölüme ayrılır. illk devlet sınavına başvurabilmek için sosyal bilgiler programı çerçevesinde modül sınavlarını başarılı bir şekilde vermiş olması gerekir. Sınav için kayıtlar $6-7$ ay öncesinden sınav merkezine yapılır (www.unimuenchen.de). Siyasi teoriler, siyasi sistemler, uluslararası siyaset sosyal teori çerçevesinde federal almanya cumhuriyetinin sosyal yapısı ve eğitim bilimleri gibi alanlardan sorular sorulur.

\section{Alan ya da Yan Alan Uygulaması (Fachpraktikum)}

Bu uygulamalar dışında, öğretmen adayları tüm dersleri verdikten, bitirme sınavını başarıyla tamamladıktan ve birinci kamu personeli sınavını geçtikten sonra, eyaletlere göre 18 aydan 24 aya kadar süren bir staj (Lehramtsreferendariat) dönemi geçirirler. Almanya'da asıl olarak öğretmen uygulama eğitimi bu aşamada verilmektedir. Bu staj döneminin ilke ve hedefleri fakültede verilen 
eğitimde yapılan uygulamalarla benzerdir. Ancak stajyerlik döneminde öğretmen adayı artık tam zamanlı ve maaşı ılarak çalışır. Bu dönemde stajyer öğretmen adayı yine bir formasyon uzmanı (eğitim uzmanı) ve en az bir alan uzmanı danışmanlığında tecrübeli öğretmenlerin derslerini izler, kendisi ders hazırlayıp sunar ve öğrencilere rehberlik eder. Bu stajı başarıyla tamamlayan öğretmen adayları II. Kamu Personeli Sınavına girmeye hak kazanır. Bitirme sınavını her eyalet kendisi yapar. Bir eyalette kazanılmış bir bitirme sınavıyla, istisnalar dışında, birçok eyalette öğretmenliğe atanmak mümkündür. Bu ikinci Kamu Personeli Sınavı bir bitirme tezi, bir ders uygulaması ve bütün staj döneminin ders etkinlikleri, eğitmenlik, danışmanlık ve muhakeme gücü yeterliklerinin en az iki danışmanı tarafından rapor ve tutanaklar ışığında değerlendirilmesini kapsamaktadır. İkinci Kamu Personeli Sınavını başarıyla tamamlayan herkes, öğretmen ihtiyacı ve alımı ilan etmiş okullara başvurur ve atanır (www.unimuenchen.de).

Stajlar dâhil tüm uygulamalar, bu konuda uzmanlaşmış olan öğretmenlik uygulaması danışmanlarının yönetim ve gözetiminde gerçekleşir. Bu uzman danışmanlar üniversite bünyesinde kurulmuş olan Okul Uygulamaları Eğitimi Merkezi (Schulpraktische Studien) biriminde çalışırlar. Bu birim özellikle staj dönemindeki öğretmen adaylarının katılımının zorunlu olduğu seminerleri düzenler. Bu seminerler staj dosyası hazırlama, öğrenci başarılarını değerlendirme, genel ve özel öğretim yöntemlerine yönelik konuları içerir. Bu birimde uygulamanın etkililiği ve sorunları danışman ve uygulama yapan öğretmen adayları tarafından, grup halinde veya bireysel olarak tartışılır ve geliştirilir.

Birinci devlet sınavını kazanan adaylar, yaklaşık iki yıl süreli bir stajyerlik dönemini de başarıyla bitirdikleri takdirde ikinci bir kamu personeli sınavına (II. Staatsexamen) girme hakkını elde ederler. İkinci devlet sınavında başarılı olan ağretmen adayları asıl olarak atanmaya hak kazanırlar (Abazaoğlu, 2014). Öğretmenler devlet memuru statüsünde kabul edilir ve maaşları eyalet yönetimleri tarafından ödenir (Gül, 2015).

\section{Tartışma ve Sonuç}

Alman eğitim sistemi eyaletlere göre farklılık göstermektedir. Eyaletler eğitim sistemini değiştirme ve geliştirme haklarına sahiptir. Farklı eyaletlerde üniversiteler ve enstitüler bünyesinde Sozialkunde (Sosyal Bilgiler) öğretmenliği eğitimi verilmektedir. Öğretmen yetiştirme programlarına kayıt yaptırabilmek için "Abitur" sınavlarını başarıyla geçen öğretmen adayları üniversite eğitimini başarıyla tamamladıktan sonra birinci devlet sınavına (Staatexamen) girerler. Yazılı ve sözlü olmak üzere iki aşamadan oluşan bu sınavda başarılı olmaları halinde stajer öğretmen olarak atanırlar. 18 ile 24 ay arasında değişen sürelerde stajyer öğretmenlik eğitimini başarıyla tamamlayan öğretmenler ikinci devlet sınavına (Staatexamen) girerler. Yine yazılı ve sözlü olmak üzere iki aşamadan oluşan ikinci devlet sınavının başarılı bir şekilde kazanmaları halinde asil öğretmen olarak atanmaktadırlar. Türkiye de ise Öğretmen Adayları Merkezi Sınav Sistemiyle üniversitelere yerleşmektedir. Lisans eğitiminden sonra merkezi sınava (KPSS) girdikten sonra başarılı olmaları sonucunda öğretmen olarak atanmakta yeni bir merkezi sınava girmemektedirler.

Almanya'nın birçok üniversitesinde Sosyal Bilgiler (Sozialkunde) bölümü bulunmaktadır. Sosyal Bilgiler bölümü genel olarak Eğitim ve Sosyal Bilimler Fakülteleri bünyesinde yer almaktadır. Gymnasium (Ortaokul ve Lise), Realschule (Ortaokul ve lise), Hauptschule (Ortaokul), Gesamtschule (Ortaokul ve lise) ve Grundschule okullarında ders vermek üzere öğretmenler yetiştirilmektedir. Türkiye'de Eğitim Fakülteleri bünyesinde Sosyal Bilgiler Öğretmenliği bölümleri yer almakta okul türlerine göre bölümler yer almamaktadır.

Sosyal Bilgiler Eğitimi Bilim Dalı, Siyaset bilimi, Sosyoloji ve Günümüz Tarihi olmak üzere üç değişik alandan meydana gelmektedir. Eğitim süresi içerisinde sosyal bilgiler alanından 10 adet zorunlu modül alınma zorunluluğu vardır. Eğitim süresi 9 sömesterden oluşmaktadır. Eğitim bilimleri eğitimi, pedagoji, okul pedagojisi ve psikoloji gibi alanlardan oluşmaktadır. Bu üç alandan toplam 36 ECTS kredisi alınması gerekir. Öğretmen adayları 2. veya 3. yarıyılda haftanın bir gününü 5 ile 8 kişilik gruplar halinde okullara giderek dersleri takip ederler. Lisans eğitiminden sonraki uygulama sürecinde öğretmen adayı tam zamanlı ve maaşlı olarak görev yapar. Bu dönemde stajyer öğretmen adayı yine 
bir formasyon uzmanı (eğitim uzmanı) ve en az bir alan uzmanı danışmanlığında tecrübeli öğretmenlerin derslerini izler, kendisi ders hazırlayıp sunar ve öğrencilere rehberlik eder. İkinci devlet sınavını her eyalet kendisi yapar. Bir eyalette kazanılmış bir bitirme sınavıyla, istisnalar dışında, birçok eyalette öğretmenliğe atanmak mümkündür. Bu ikinci Kamu Personeli Sınavı bir bitirme tezi, bir ders uygulaması ve bütün staj döneminin ders etkinlikleri, eğitmenlik, danışmanlık ve muhakeme gücü yeterliklerinin en az iki danışmanı tarafından rapor ve tutanaklar ışığında değerlendirilmesini kapsamaktadır. Stajlar dâhil tüm uygulamalar, bu konuda uzmanlaşmış olan öğretmenlik uygulaması danışmanlarının yönetim ve gözetiminde gerçekleşir.

Türkiyede Sosyal Bilgiler Öğretmenliği bölümlerinde diğer disiplinlere ait konular da işlenmekle birlikte ağılıklı olarak Tarih, Coğrafya ve Vatandaşlık bilgisi alanlarına yer veilmektedir. Lisans eğitimi süürecinde pedagojik formasyon dersleri verilmekte okul deneyimi ve öğretmenlik uygulaması dersleri Milli Eğitim Bakanlığına bağlı ortaokullarda gerçekleştirilmektedir. Lisans eğitiminden sonra atanan öğretmenler bir yıllık bir eğitimden geçmekte, öğretmen gözlenmekte yılsonunda hazırlanan raporlar dorultusunda asil öğretmenliğe geçişleri sağlanmaktadır.

\section{KAYNAKÇA}

Abazaoğlu, i. (2014). "Dünyada Öğretmen Yetiştirme Programları ve Öğretmenlere Yönelik Mesleki Gelişim Uygulamaları", Turkish Studies: International Periodical For The Languages, Literature And History Of Turkish Or Turkic 9, (5), ss.1-46.

Führ, C. (1997). Deutsches bildungswesen seit 1945. grundzüge und probleme. Neuwied.

Gül, Y. E. (2015). "Öğretmen Yetiştirme Sistemlerinin Karşılaştırılması: Almanya ve Kırgızistan Örneği." Uluslararası Türk Eğitim Bilimleri Dergisi, 4, ss. 68-83.

Harder, P. (2012). Werthaltungen und Ethos von Lehrern Empirische Studie zu Annahmen über den guten Lehrer, Dissertation, Fakultät Sozial- und Wirtschaftswissenschaften der Otto-Friedrich Universität Bamberg.

Demirel, Ö. (2000). Karşılaş̧ırmalı eğitim, Pegem Yayıncılık, Ankara.

Kantos, Z. E. (2009). Karşılaştırmalı Eğitim Sistemleri, Balcı, A. (Ed), 2. Baskı, Pegem Akademi, Ankara.

Keçici, S. E. (2011) "Almanyada Öğretmen Eğitimi”, M.Ü. Atatürk Eğitim Fakültesi Eğitim Bilimleri Dergisi, 34, ss. 117-132.

Kempf, H. P. (2002). Werteaspekte im Deutschunterricht der Realschule Repräsentative Paradigmen und literaturdidaktische Exemplifizierungen, Dissertation, Philosophischen Fakultät II der Julius-MaximiliansUniversität Würzburg.

Kricke, M. (2014). Lernen und Lehren in Deutschland und Finnland - eine empirische Studie zu Schulsystem und LehrerInnenbildung im Ländervergleich, Dissertation, der Humanwissenschaftlichen Fakultät der Universität zu Köln.

Sağlam, M. (1999). Avrupa ülkelerinin eğitim sistemleri. Anadolu Üniversitesi Yayınları, Eskişehir.

Sözen, S. ve Ayşegül, Ç. (2013). "Türkiye, Avusturya ve Almanya Öğretmen Yetiştirme Sistemlerinin Incelenmesi." Uşak Üniversitesi Sosyal Bilimler Dergisi, 6, ss. 220-237.

Tonga, D. (2012) "Sosyal Bilgiler Öğretmenliği Lisans Programının Değerlendirilmesi." Türk Eğitim Bilimleri Dergisi, 10,(4), ss. 779-803.

https://studienwahl.de/finder/detail/40287?prefill7BstudytypeASozialkundeD\#ffe, erişim tarihi: 27.02.2020

https://www.unimuenchen.de/studium/studienangebot/studiengaenge/studienfaecher/sozialkun /lehramt neu/la gymn 1/index.html. Erișim tarihi 29.02.2020. 